\title{
Status and habitat associations of birds on Lembata Island, Wallacea, Indonesia, with reference to a simple technique for avifaunal survey on small islands
}

\author{
COLIN R. TRAINOR
}

\section{Summary}

The islands of Wallacea were surveyed most intensely by field ornithologists in the nineteenth century, and again in the 1990s. However, the status and habitat use of bird species on many islands remains unknown. This study examined birds in several natural and disturbed habitats on Lembata (also known as Lomblen) Island, Indonesia. A total of 78 bird species were recorded including six endemic to the Lesser Sundas, an additional three Wallacean endemics and a total of 27 resident forest species. Including published records, 91 bird species have been recorded for Lembata. Extrapolation from the cumulative number of new species in the 45 samples gave an expected Total Bird Richness of 103.4 species. The frequency of occurrence of Lesser Sundas endemic bird species, all Wallacean endemics and Lesser Sundas endemic subspecies, forest-dependent species and frugivores was greatest in closed canopy forest (at higher elevations). Conversely, generalist "Australo-Papuan" species, granivores and nectarivores occurred more frequently in lowlands (including human-modified habitats). Protected area proposals were made in 1982, but there has been no management of natural areas for biological conservation on Lembata. Conservation activities aiming to stem forest loss and fragmentation in an Important Bird Area in southern Lembata, which includes significant populations of the Flores Green Pigeon Treron floris (Globally Vulnerable), may be an important step. Merits of the "Species list" survey method are discussed.

\section{Introduction}

Islands are hotspots of endemism, extinction and urgency of conservation action: $89 \%$ of 116 known bird extinctions since $\mathrm{AD} 1600$ have occurred on islands (Gaston and Blackburn 1995). Indonesia comprises the most biologically diverse archipelago on earth, has numerous centres of avian endemism (Stattersfield et al. 1998) and the highest national total of globally threatened bird species (BirdLife International 2001), yet our knowledge of the avifauna remains poor.

Indonesia has a long history of systematic priority setting for biodiversity conservation. The "National Conservation Plan" and "Biodiversity Action Plan" outline a comprehensive system of reserves (FAO/UNDP 1983, Bappenas 1993). However, many were not gazetted, and most have not been managed effectively for biodiversity conservation (Wells et al. 1999, Whitten et al. 2001).

In Wallacea, basic avifaunal distribution patterns are relatively well known 
(White and Bruce 1996, Coates and Bishop 1997, Stattersfield et al. 1998). However, within-island ecological correlates of avifaunas (Jones et al. 1995, 2001, Poulsen 1998, Poulsen and Lambert 2000) - and a broader understanding of the effects of habitat loss, fragmentation and trade - remains limited (Lambert 1993, Marsden 1998, BirdLife International 2001). Such information is important for focusing conservation and management efforts, although given the urgent threat, rapid applied approaches are needed to gather such data. Efforts by biologists and ornithologists have intensified in recent years, but several biologically important islands were last comprehensively surveyed in the nineteenth or early twentieth centuries (White and Bruce 1986).

The North Nusa Tenggara Endemic Bird Area (Stattersfield et al. 1998), covers the islands of Lombok to Alor, but most recent conservation and management activities have focused on Sumbawa, Komodo and Flores (Butchart et al. 1996, Johnstone et al. 1996, Trainor and Lesmana 2000). The "National Conservation Plan" highlighted one Lembata site as a protected area (FAO/UNDP 1983) but it was not gazetted. Lembata is the twentieth largest island in Wallacea but its avifauna is described best by a four day survey by A. Everett in 1897, and brief observations by V. Mason in 1990 and 1991. Fifty-five species were listed in a recent review (Verhoeye and Holmes 1999). In this paper, I describe the status of Wallacean endemic bird species on Lembata, and community level patterns of bird-habitat associations (allocated to bird groups based on phylogenetic distribution and ecological criteria). A simple rapid survey technique to inventory birds, and describe their habitat associations is illustrated. An annotated list of bird records has been produced in a sister report (Trainor in review).

\section{Study sites and methods}

The island of Lembata $\left(8^{\circ} 20^{\prime} \mathrm{S}, 123^{\circ} 30^{\prime} \mathrm{E}, 1,269 \mathrm{~km}^{2}, 0-1,450 \mathrm{~m}\right.$, see Figure 1), biologically one of the Lesser Sunda Islands, occurs in East Nusa Tenggara province, south Wallacea, Indonesia. The island is irregularly shaped $(80 \mathrm{~km}$ long and $8-15 \mathrm{~km}$ wide) and predominantly volcanic (83\% of land surface), limestone (13\%) and alluvium (4\%) (Noya and Koesoemadinata 1990). Lembata is physically and biologically closely linked to Flores, to which it would have been connected during the last glacial period, 8,000-12,000 years BP (Monk et al. 1997). Morphologically, Lembata can be divided into mountainous country and lowlands: the topography is mostly hilly with limited coastal plains that include alluvium and uplifted limestone terraces to $200 \mathrm{~m}$.

The climate is dry tropical with $90 \%$ of the annual rainfall $(1,000-2,000 \mathrm{~mm})$ falling from November to March, with a long, rainless dry season (AprilOctober) (RePPProT 1989). Throughout Wallacea, rainfall is strongly associated with elevation. Closed canopy forest cover is about $15 \%\left(80 \mathrm{~km}^{2}\right)$ though under the seasonal climate there is substantial savanna woodland not included in this total. The human population density of about 66 people $/ \mathrm{km}^{2}$ is slightly below the average in Nusa Tenggara (c. 75 people $/ \mathrm{km}^{2}$ ) and nationally (Monk et al. 1997). Coconut, candlenut Aleurites trisperma and cashew Anacardium are the main cash crops. Shifting agriculture is used intensively throughout Lembata (with cassava, corn, rice, peanuts and beans).

Systematic ornithological and habitat assessments were undertaken at 12 sites 


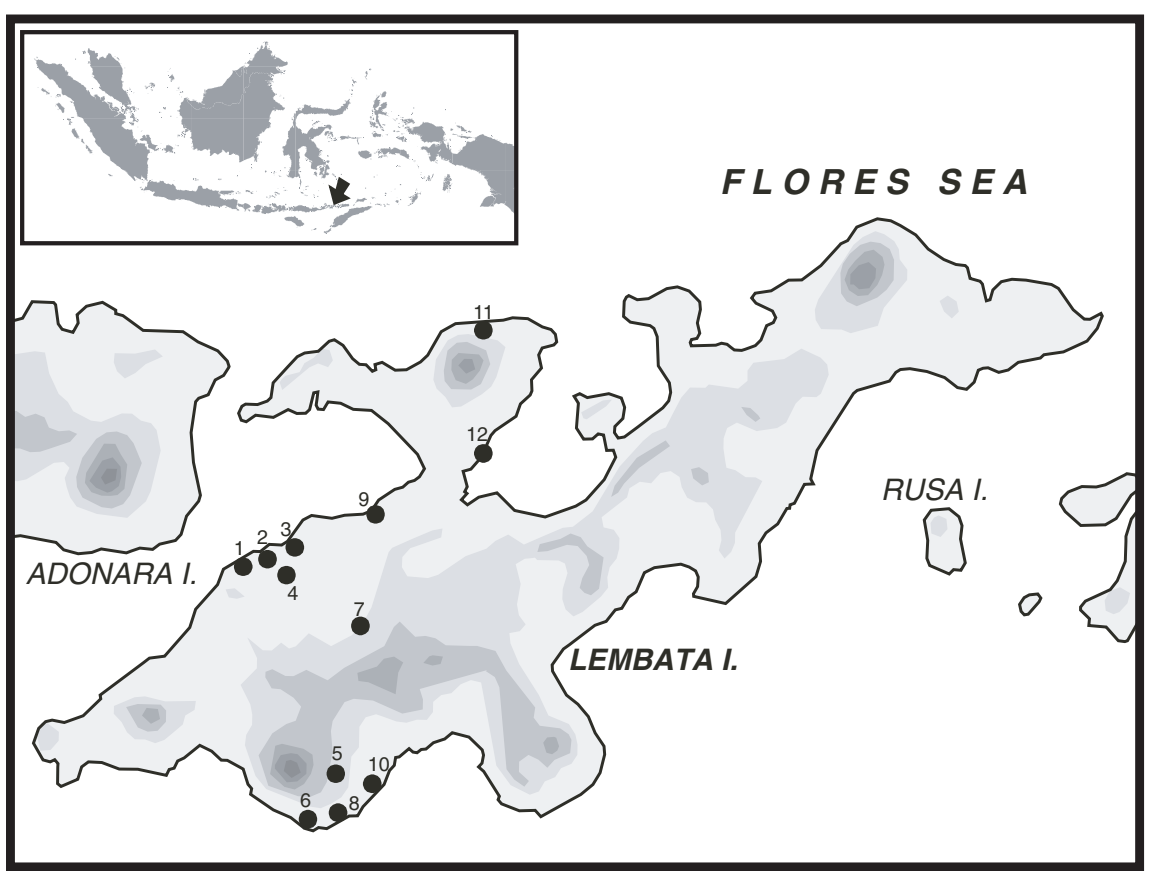

1, Lewoleba, 3kms; 2, Lewoleba harbour; 3, Lewoleba town; 4, Lewoleba (Telkom); 5, Labelekang (Puor); 6, Lelata; 7, Kalikasa road; 8, Lamalera; 9, Lewoleba airfield; 10, 3km East of Lamalera; 11, Ile Api; 12, Jontona.

Figure 1. Map of study sites on Lembata

(Figure 1), from 05h30 to 11 hoo and 16 hoo to 19 hoo (bird records including species, habitat and behavioural notes were also noted during "general observations" throughout the day). Bird surveys used the 10-species list method (or MacKinnon lists: Bibby et al. 1998) to assess composition and species frequency of occurrence. The first 10 bird species encountered in a sample area were listed, then repeated with a new list (and so on). Ten species were chosen based on the known poverty of Lembata's avifauna $(<60$ bird species in published literature prior to the current study), and a trial using to species was carried out on nearby Adonara Island $\left(497 \mathrm{~km}^{2}\right.$, see Trainor 2002) prior to arriving on Lembata. This method was not confined by either survey area (though usually each list was collected within an area of $c$. 1-3 ha) or time. Field data were collected in independent locations, however swamp forest was restricted to a single 3 ha fragment and was resampled.

Each of the 45 samples was allocated to one of six habitat types and to a geological unit (following Monk et al. 1997, Noya and Koesoemadinata 1990). Elevation was measured with an altimeter and canopy height (in metres) and canopy cover (percentage) were visually estimated in each sample location. General observations were undertaken in two habitats not covered by systematic sampling: seasonal montane forest dominated by Eucalyptus urophylla (restricted to the tops of hills and mountains) and Lontar palm savanna (present but not extensive). 


\section{Data analyses}

A data matrix comprising the 45 samples, habitat variables (habitat type, elevation and geology) and derived species groups formed the basic dataset for analysis using SPSS Version 10.0.1 for windows (SPSS 1999). Analyses of bird "species groups" included the sample sum of all recorded species (including aerial species, raptors and migrants), but single-species analyses were restricted to those bird species recorded from five or more samples.

Species groups comprised the sum of all bird species (i.e. species richness or relative species density) in distribution and ecological groupings in each sample. The data represent proportions or frequency of occurrence out of a possible 10 species (except for the sum of various ecological guilds, which excluded migrant species), in between-group comparisons.

Bird species were put into the following categories based on distributional and ecological criteria (see Appendix). "Lesser Sundas endemics" included the sum of bird species confined to the islands between Lombok and Tanimbar (all are also restricted-range); "Wallacean endemics" included Wallacean endemic bird species (including those in the former category), and thirdly, "Lesser Sundas endemic subspecies", including phylogenetic races endemic to the Lesser Sundas but excluding species in the former two groups. "Forest Bird" was the sum of species subjectively assessed as dependent on closed canopy forest habitat in the Lesser Sundas (from Butchart et al. 1996, Coates and Bishop 1997). "AustraloPapuan" was the sum of species whose ancestral affinities or origins are considered to be Sahuland (taken from White and Bruce 1986, Coates and Bishop 1997). Each species was allocated into a single group representing broad niche groups (Insectivore, Omnivore, Frugivore, Nectarivore and Granivore). Kruskal-Wallis tests were used to examine between-group differences in the mean rank of "species variables" and individual bird species across habitat types.

Total Bird Species Richness for Lembata was extrapolated using Chao 1 (see Colwell and Coddington 1994) where the frequency of singletons (birds recorded only once in samples) and doubletons are used to derive a total estimate, thus:

$$
\mathrm{S}_{1}=\mathrm{S}_{\mathrm{obs}}+a^{2} / 2 b \text {, }
$$

where $S_{\text {obs }}$ is the number of species recorded, $a$ the number of singletons, and $b$ the number of doubletons. The variance of the estimated richness is $\operatorname{var}\left(\mathrm{S}_{1^{*}}\right)=$ $\mathrm{b}\left[(a / b)^{4} / 4+(a / b)^{3}+(a / b)^{2} / 2\right]$ (see Fjeldsa 1999).

Avian nomenclature and taxonomy follow Inskipp et al. (1996) with the following exceptions, which follow White and Bruce (1986): Barred Dove Geopelia mangei and Wallacean Drongo Dicrurus densus.

\section{Results}

Overall bird composition

A total of 78 bird species was recorded during the survey: 73 species were observed in the 45 10-species samples, and five additional species were observed during general observations (Snipe Gallinago sp. (?megala) and Varied Triller Lalage sueurii) or reliably identified by local informants. Compilation of project 
records and those previously published gave 91 bird species, 73 of which were resident (see Appendix). Forest-dependent bird species comprised more than one-third of residents (27 species). Total Richness of Lembata's avifauna was estimated to be 103.4 (101.2-105.6) using the Chao 1.

Lembata has six bird species endemic to the Lesser Sundas (all are restrictedrange species) and an additional four species endemic to Wallacea (or almost so including Yellow-crested Cockatoo Cacatua sulphurea). Twenty-five resident bird species belong to Lesser Sundas endemic races. Almost half (48\%) of resident birds comprise restricted-range phylogenies. Two globally threatened species occur: Yellow-crested Cockatoo (Critically Endangered) and Flores Green Pigeon Treron floris (Vulnerable). Two Near Threatened species are also present: Malaysian Plover Charadrius peronii and Great-billed Heron Ardea sumatrana.

\section{Habitat description}

Of the 45 samples, 16 occurred in non-forest lowland habitats (types 1-3 below), and 27 were of closed forest (types $4-6$ below).

1. Coastal complex (eight samples) was a mix of mostly human-modified habitats in coastal situations from sea level to about $100 \mathrm{~m}$ on alluvium and limestone. It would naturally also include swamp forest and mangroves, but these habitats are structurally, floristically and avifaunally distinctive. Included here were coconut plantations, grass and shrublands within and around villages and the coast, and minor habitats such as an estuary. Canopy cover varied from o to about $30 \%$ (mostly $<10 \%$ ), height to $20 \mathrm{~m}$, with limited structural diversity.

2. Eucalyptus alba savanna (three samples) was an open savanna to $15 \mathrm{~m}$ (5-15\% canopy cover) dominated by Eucalyptus alba with a tussock grass understorey, mainly occurring on undulating hills and ridges. Samples were taken on carbonate and volcanic substrates from sea level to $300 \mathrm{~m}$. This habitat type is widespread (perhaps $15-20 \%$ of the land surface) but increasingly modified by clearance, cutting for firewood and shifting agriculture, where crops such as rice, peanuts and corn are planted.

3. Mangroves (five samples) were a distinctive and relatively extensive habitat type $\left(>1 \mathrm{~km}^{2}\right)$ in the Lewoleba and Waicuga Bays. Mature trees (Brugiera, Ceriops, Rhizophora) reached $15 \mathrm{~m}$ with canopy closure of more than $50-70 \%$, and were often fringed by tropical dry forest. There were patches of highly degraded mangroves, cut by local communities for firewood. However, the majority maintained their natural structure.

4. Swamp forest (three samples) was represented by a single closed forest on alluvium near Lewoleba. The patch covered $2-3$ ha, with figs Terminalia and a diverse range of trees reaching $25 \mathrm{~m}$ with canopy closure of $60-80 \%$. A spring flowed through the forest with extensive inundated swamp surrounding it, covered in Pandanus and clumps of Acrostichum speciosum.

5. Tropical dry forest ( 15 samples) occurred on carbonaceous and volcanic substratum growing to $15 \mathrm{~m}$ with emergent trees in moist gullies to $25 \mathrm{~m}$. Dry tropical forest was extensive along the south coast of Lembata. Near Lewoleba dry tropical forest occurred from sea level to about $400 \mathrm{~m}$ and was mostly restricted to gully situations that were fire protected. 
6. Tropical moist deciduous forest (11 samples) occurred on fertile volcanic soils; the remaining fragments occured in steep valleys unsuitable for agriculture (and topographically protected from fire). Occurred from about 300 to 1,000 $\mathrm{m}$; canopy height reached $25-35 \mathrm{~m}$ with a canopy closure of $60-80 \%$.

\section{Bird community composition}

Only 14 species occurred relatively frequently (in 10 or more samples); there were 18 single and 11 double occurrences. The 10 most frequently occurring species included, among others: Helmeted Friarbird Philemon buceroides (40 of 45 samples), Wallacean Drongo (26), Spotted Dove Streptopelia chinensis (25), Flamebreasted Sunbird Nectarinia solaris (18), Scaly-breasted Munia Lonchura punctulata (18) and Black-fronted Flowerpecker Dicaeum igniferum (16). Infrequently recorded species included Broad-billed Monarch Myiagra ruficollis (3), Elegant Pitta Pitta elegans (2), Molluccan Scops-owl Otus magicus (2, recorded during the few samples at dusk) and a group of waders recorded in a single sample (Grey Plover Pluvialis squatorola, Wood Sandpiper Tringa glareola, Ruddy Turnstone Arenaria interpres and Malaysian Plover).

The frequency of occurrence of 14 of the 30 species (recorded in five or more samples) varied significantly between habitats (Table 1 ). Frugivorous bird species were most associated with closed canopy forest, followed by Wallacean endemic species, forest birds, Lesser Sundas endemic species, and less strongly, Lesser Sundas endemic races.

\section{Coastal complex}

Coastal complex was the most biologically distinctive "habitat" type with 12 bird species confined to it. However, almost one-third of these were transient Palearctic migrants (e.g. Charadrius plovers, sandpipers and Ruddy Turnstone). There were very few regional endemics and no frugivores. Grassland (e.g. Lesser Coucal Centropus bengalensis, Zitting Cisticola Cisticola juncidis), generalist (e.g. Spotted Dove and sunbirds Nectarinia sp.) and Australo-Papuan species typified this habitat.

\section{Mangroves}

A total of 26 species were recorded in mangrove samples, and two others during general observations. Australo-Papuan species and granivores (in mangrove edge habitat) were dominant, while regional endemics occurred infrequently. Several mangrove-confined species characterized this habitat well: Little Pied Cormorant Phalacrocorax melanoleucos, Great-billed Heron, Little Heron Buturoides striatus, Common Kingfisher Alcedo atthis, Broad-billed Monarch, and Rufous Fantail Rhipidura rufifrons. Omnivores (Stork-billed Kingfisher Halcyon capensis, Brahminy Kite Haliastur indus and Large-billed Crow Corvus macrorhynchus) were frequent.

\section{Eucalyptus alba Savanna}

Eucalyptus alba-dominated savanna had the least specialized avifauna with only one confined species, Varied Triller. There were few restricted-range species, but 
Table 1. An ordered two-way table portraying differential frequency of occurrence across habitats.

\begin{tabular}{|c|c|c|c|c|c|c|c|}
\hline & $\begin{array}{l}\text { Coastal } \\
\text { complex }\end{array}$ & $\begin{array}{l}\text { E.alba } \\
\text { savanna }\end{array}$ & $\begin{array}{l}\text { Man- } \\
\text { groves }\end{array}$ & $\begin{array}{l}\text { Swamp } \\
\text { forest }\end{array}$ & $\begin{array}{l}\text { Dry } \\
\text { tropical } \\
\text { forest }\end{array}$ & $\begin{array}{l}\text { Moist } \\
\text { deciduous } \\
\text { forest }\end{array}$ & $\chi^{2}$ \\
\hline Number of lists & 8 & 3 & 5 & 3 & 15 & 11 & \\
\hline Frugivore & o & o & o & $1.3 \pm 0.3$ & $1.9 \pm 0.3$ & $3.2 \pm 0.2$ & $34 \cdot 1^{* * *}$ \\
\hline Forest-dependent & $1.6 \pm 0.3$ & $2.3 \pm 0.7$ & $2.8 \pm 0.8$ & $4.7 \pm 0.3$ & $3.0 \pm 0.2$ & $7.0 \pm 0.3$ & $32.2^{* * * *}$ \\
\hline $\begin{array}{l}\text { Wallacean } \\
\text { endemic }\end{array}$ & $0.6 \pm 0.3$ & $1.7 \pm 0.3$ & $0.8 \pm 0.4$ & $1.0 \pm 0.6$ & $3.1 \pm 0.2$ & $2.3 \pm 0.3$ & $24.8^{* * * *}$ \\
\hline $\begin{array}{l}\text { Lesser Sundas } \\
\text { endemic }\end{array}$ & $0.1 \pm 0.1$ & $1.3 \pm 0.3$ & $0.6 \pm 0.4$ & $0.3 \pm 0.3$ & $2.3 \pm 0.3$ & $1.6 \pm 0.3$ & $23 \cdot 4^{* * *}$ \\
\hline $\begin{array}{l}\text { Lesser Sundas } \\
\text { end ssp }\end{array}$ & $2.6 \pm 0.6$ & $3.7 \pm 0.9$ & $2.6 \pm 0.9$ & $3.3 \pm 0.3$ & $3.5 \pm 0.3$ & $5.4 \pm 0.3$ & $16.6^{* *}$ \\
\hline Australo-Papuan & $1.2 \pm 0.2$ & $2.7 \pm 0.9$ & $3.0 \pm 0.8$ & $1.7 \pm 0.5$ & $1.7 \pm 0.2$ & $2.6 \pm 0.2$ & $14.2^{*}$ \\
\hline Nectarivore & $1.8 \pm 0.1$ & $2.7 \pm 0.7$ & $2.4 \pm 0.5$ & $1.3 \pm 0.3$ & $1.9 \pm 0.1$ & $1.3 \pm 0.2$ & $14.0^{*}$ \\
\hline Granivore & $1.7 \pm 0.4$ & $2.3 \pm 0.7$ & $1.2 \pm 0.4$ & $1.7 \pm 0.3$ & $1.2 \pm 0.2$ & $0.5 \pm 0.2$ & $12.1^{*}$ \\
\hline Saxicola coprata & 62 & 33 & & & 13 & & $15 \cdot 4^{* *}$ \\
\hline Actitus hypoleucos & 37 & & 20 & & 6 & & 8.3 \\
\hline $\begin{array}{l}\text { Philemon } \\
\text { buceroides }\end{array}$ & 100 & 100 & 80 & 33 & 93 & 91 & $11.2^{*}$ \\
\hline Falco mollucensis & 12 & 100 & & 33 & 26 & & 10.3 \\
\hline $\begin{array}{l}\text { Streptopelia } \\
\text { chinensis }\end{array}$ & 50 & 100 & 60 & 67 & 67 & 27 & 6.8 \\
\hline Nectarinia solaris & 12 & 100 & 40 & & 80 & & $25 \cdot 7^{* * *}$ \\
\hline Cisticola juncidus & 62 & 67 & & & & 9 & $20.9^{* *}$ \\
\hline $\begin{array}{l}\text { Lonchura } \\
\text { punctulata }\end{array}$ & 62 & 67 & & 67 & 46 & 18 & 9.0 \\
\hline Gerygone sulphurea & 12 & 67 & 20 & & 13 & & $9 \cdot 5$ \\
\hline $\begin{array}{l}\text { Centropus } \\
\text { bengalensis }\end{array}$ & 37 & 67 & & 33 & 33 & 27 & 4.2 \\
\hline $\begin{array}{l}\text { Phylloscopus } \\
\text { borealis }\end{array}$ & & 33 & & & 20 & 10 & 4.6 \\
\hline $\begin{array}{l}\text { Artamus } \\
\text { leucorhynchus }\end{array}$ & & 33 & 20 & & 20 & 9 & 3.6 \\
\hline Geopelia maugei & 37 & & 60 & 33 & 6 & 9 & 9.8 \\
\hline Haliastur indus & 12 & & 40 & & 13 & & 6.3 \\
\hline $\begin{array}{l}\text { Corvus } \\
\text { macrorhynchus }\end{array}$ & & & 40 & & 26 & 9 & 6.5 \\
\hline $\begin{array}{l}\text { Nectarinia } \\
\text { jugularis }\end{array}$ & 75 & & 60 & 100 & 6 & & $26.7^{* * *}$ \\
\hline Halcyon chloris & 50 & 33 & & 60 & 100 & 40 & $12.9^{*}$ \\
\hline $\begin{array}{l}\text { Eudynamys } \\
\text { scolopacea }\end{array}$ & 12 & 33 & & 100 & 13 & 54 & $15 \cdot 4^{* *}$ \\
\hline $\begin{array}{l}\text { Ptilinopus } \\
\text { melanospila }\end{array}$ & & & & 67 & 20 & 36 & $9 \cdot 7$ \\
\hline $\begin{array}{l}\text { Rhipidura } \\
\text { rufiventris }\end{array}$ & & & 60 & 67 & & & $25 \cdot 5^{* * *}$ \\
\hline Dicrurus densus & 37 & 33 & 20 & 67 & 80 & 63 & 8.1 \\
\hline Zosterops wallacei & & & & & 73 & 27 & $20.6^{* *}$ \\
\hline Oriolus chinensis & & & & 33 & & 81 & $30.9^{* * *}$ \\
\hline $\begin{array}{l}\text { Pachycephala } \\
\text { pectoralis }\end{array}$ & & & 40 & 67 & 13 & 81 & $20.9^{* *}$ \\
\hline Dicaeum igniferum & & & & & 53 & 72 & $18.7^{* *}$ \\
\hline $\begin{array}{l}\text { Trichoglossus } \\
\text { euteles }\end{array}$ & & 33 & 20 & & 13 & 36 & 5.6 \\
\hline
\end{tabular}


Table 1. Continued

\begin{tabular}{lcllrlrc}
\hline & $\begin{array}{l}\text { Coastal } \\
\text { complex }\end{array}$ & $\begin{array}{l}\text { E.alba } \\
\text { savanna }\end{array}$ & $\begin{array}{l}\text { Man- } \\
\text { groves }\end{array}$ & $\begin{array}{l}\text { Swamp } \\
\text { forest }\end{array}$ & $\begin{array}{l}\text { Dry } \\
\text { tropical } \\
\text { forest }\end{array}$ & $\begin{array}{l}\text { Moist } \\
\text { deciduous } \\
\text { forest }\end{array}$ & $\chi^{2}$ \\
\hline $\begin{array}{l}\text { Oriolus chinensis } \\
\text { Ducula aenea }\end{array}$ & & & 33 & & 81 & $30.9^{* * * *}$ \\
$\begin{array}{l}\text { Hypothymis azurea } \\
\text { Rhipidura diluta }\end{array}$ & 25 & & & & 13 & 54 & $14 \cdot 1^{*}$ \\
Collocalia esculenta & & & 33 & 26 & 54 & 6.7 \\
\hline
\end{tabular}

Significance levels from Kruskal-Wallis Test: ${ }^{*} P<0.05 ;{ }^{* *} P<0.01 ;{ }^{* * *} P<0.001$. (Note that the high number of significance tests increases the number of significant results by chance). Values for phylogenetic and ecological species groups is the proportion from a possible 1o species; values for individual species is the sample frequency of occurrence (as a percentage). Highest across-group values are shown in bold. There was no difference in the relative abundance of omnivores, non-passerines and passerines across habitats.

the frequency of occurrence of Lesser Sundas endemic races was high. The relative abundance of nectarivorous (e.g. Olive-headed Lorikeet Trichoglossus euteles, Helmeted Friarbird and Flame-breasted Sunbird) and granivorous species was greatest in this savanna habitat.

\section{Swamp forest}

Swamp forest had few regional endemics, but these included Flores Green Pigeon. Forest birds, including frugivores such as Asian Koel Eudynamys scolopaceae, Black-naped Fruit Dove Ptilinopus melanospila and Black-naped Oriole Oriolus chinensis, were abundant. Several grassland species (Zitting Cisticola and Scaly-breasted Munia) were recorded in grasslands fringing this habitat.

\section{Tropical dry forest}

Dry tropical forest was rich in forest birds, Lesser Sundas (five of the six species) and Wallacean endemics. Forest-dependent birds such as Wallacean Drongo, Helmeted Friarbird and open country species such as Yellow-spectacled Whiteeye Zosterops wallacei, sunbirds and Collared Kingfisher Todiramphus chloris also characterized this habitat.

\section{Tropical moist deciduous forest}

Moist deciduous forest was richest in true forest bird species, and had six species confined to it. It had the lowest proportion of Australo-Papuan species, but richness of regional endemics was relatively high, particularly races. Characteristic species included a suite of frugivores (Little Cuckoo Dove Macropygia ruficeps, Green Imperial Pigeon Ducula aenea, Black-naped Oriole and Hill Myna Gracula religiosa). Passerine insectivores included: Brown-capped Fantail Rhipidura diluta, Black-naped Monarch Hypothymis azurea, Asian Paradise Flycatcher Tersiphone paradisi and Grey-headed Canary Flycatcher Culicicapa ceylonensis. 


\section{Conservation status of Wallacean endemic species}

None of the Wallacean endemic bird species occurring on Lembata are threatened with extinction, with the exception of two hole-nesting parrots (Olive-headed Lorikeet and Yellow-crested Cockatoo). Their fidelity to nesting cavities and feeding habits in accessible modified habitats makes capture easy and thus increases their susceptibility to population decline and extirpation on small islands.

Olive-headed Lorikeet is a restricted-range species endemic to the Lesser Sundas, occurring on Timor, Adonara (Trainor 2002), Pantar, Alor, Wetar and nine of the "south-west islands" (Coates and Bishop 1997). It was occasional in pairs and small flocks, from sea level to at least $900 \mathrm{~m}$, with about 50 individual contacts (of 2-6 birds) over 13 days. One flock of 20 was observed feeding in a flowering Tamarindus indica tree near Lewoleba in Eucalyptus alba savanna. Six hatchlings (1-2 weeks old) were photographed at the Lewoleba market, indicating that breeding took place at the end of the dry season. Local informants considered that Olive-headed Lorikeet had declined on Lembata because of trapping for the cage bird trade. This species is poorly known throughout its range.

Barred Dove is widespread in the south-east Molluccas and Lesser Sundas ( 36 islands listed in Coates and Bishop 1997) preferring savannas or highly modified landscapes. This species was widespread and common on Lembata. Typically occurring in small flocks, it was particularly common adjacent to mangroves and in modified coastal habitats.

Flores Green Pigeon is endemic to Lombok, Sumbawa, Komodo (D. Agista verbally 2001), Flores, Pulau Besar, Solor, Lembata, Pantar and Alor, possibly also Flores Sea islands (BirdLife International 2001). The species was collected on Lembata in May 1897 (Hartert 1898) and project observations are the first published records for Lembata in 103 years. It was locally common with records on five of 13 days, but not enough data were collected for statistical analysis. Near Lewoleba, in swamp forest 12-15 Flores Green Pigeons were observed feeding in a fruiting fig tree and in courtship flights. Several individuals fed on small red figs during a one hour observation period. A flock of at least 15 individuals was observed feeding in the canopy of several trees within the village of Lamalera. The ease with which this species was observed within a village and near the major town on the island, supported by discussions with local people, indicated that this species is widespread, relatively common and under low-level hunting pressure.

Lembata covers roughly $3 \%$ of the potential global distribution of Flores Green Pigeon but the relative frequency of records is bettered only by observations on Pulau Besar $\left(65 \mathrm{~km}^{2}\right)$ where Butchart et al. (1996) reported it as "frequent" (six flocks). This species is either rare (Sumbawa) or uncommon (Flores) on the large islands of the North Nusa Tenggara Endemic Bird Area (Butchart et al. 1996, Trainor and Lesmana 2000). Given the broad habitat use by this species on Lembata, and the extensiveness of such habitat, Lembata probably supports significant populations of this species.

Yellow-crested Cockatoo is a Critically Endangered endemic to Wallacea plus Nusa Penida and the Maselembo islands (BirdLife International 2001). There are no published records for Lembata, but local people know it well. The village 
head of Puor indicated that he had not observed Yellow-crested Cockatoo since about 1988 in that area. Brief surveys in the late 1980s also failed to record it (Mochtar 1989). Several local informants considered that this species may be extinct or almost so on Lembata, through a combination of capture for the bird trade and persecution as a crop pest.

Brown-capped Fantail is an active understorey insectivore endemic to Sumbawa, Sangeang (Johnstone et al. 1996), Flores and Lembata, with the race diluta known only from Flores and Lembata. It was infrequently recorded, in Tropical Dry Forest and Tropical Moist Deciduous Forest, particularly in shrubby gullies $(200-700 \mathrm{~m})$. It was unrecorded from Adonara during recent observations (Trainor 2002) but may occur.

Wallacean Drongo is endemic to south-east Maluku (Seram Laut, Watubela and Kai Islands) and is widespread and typically common in the Lesser Sundas. It was the second most frequently recorded bird on Lembata (26 samples) with observations from all wooded habitats (o-900 $\mathrm{m}$ ).

Yellow-spectacled White-eye is endemic to Sumbawa, Komodo, Rinca, Flores, Adonara (Trainor 2002), Lembata and Sumba. This species generally prefers dense scrub in tropical dry forest or highly modified agricultural land. On Lembata however, it was recorded only in closed canopy forest, and was most common in thickets of siam weed Chromalaena odorata to at least $900 \mathrm{~m}$ within this habitat.

Black-fronted Flowerpecker is known from Sumbawa, Moyo (Johnstone et al. 1996), Komodo, Flores, Adonara (Trainor 2002), Lembata, Pulau Besar, Pantar and Alor, where it prefers degraded forest and wooded cultivation, especially below 1,000 m. On Lembata, this species was strongly associated with closed canopy forest in the hills, although it is typically considered a lowland generalist throughout its range.

Flame-breasted Sunbird is widespread in Nusa Tenggara: Sumbawa, Flores, Adonara (Trainor 2002), Lembata, Alor, Semau, Roti, Timor and Wetar (and numerous small islands: author's unpubl. data). It is a common and widespread nectarivore, which strongly favoured Eucalyptus savanna and tropical dry forest in this study.

\section{Discussion}

This study reports on the use of a simple and effective bird survey method and describes some significant results on globally restricted-range and threatened bird species. Several advantages and weaknesses of the chosen census method, conservation implications and suggestions for additional study are discussed below.

\section{Bird census method}

The "10-species list" sample methodology used here has several advantages, primarily its simplicity to execute and ease of analysis. However, it also introduces several possible biases. It provides a useful inventory of species, allows for predictions of total species richness, and allows relatively robust contrast analyses between site, habitat or disturbance categories. Censuses involving 
active searching (an advantage in dense tropical forest) can be conducted continuously, with a high percentage of observations included in a database (Fjeldsa 1999). The lack of temporal or spatial limits could introduce several biases. In bird-poor habitat, does the extra time or extra census area needed to obtain the 1o species mean that rare species or "skulking" species are more likely to be recorded? Coastal complex, for example, was particularly poor in species but generalist species that characterize this habitat were recorded during the extra effort made (rather than rare species). There is also good agreement in the rank frequency of occurrence of a range of bird species, compared with those recorded on nearby Alor Island using timed point counts performed along transects (e.g. Helmeted Friarbird was ranked first on both islands, author's unpubl. data). Quantifying "10-species lists" by time may not be feasible, but setting a census area of 1 or 2 ha (depending on local environmental conditions) may be of value to improve repeatability.

In Wallacea, the variable circular plot method has been used successfully to determine bird densities, population size and differential habitat associations (using the Distance programme e.g. Jones et al. 1995, Poulsen and Lambert 1998). There are several difficulties with this method, particularly for inexperienced surveyors (surveying from a point rather than active searching is one). In this study there were few target bird species for which density and population estimates would be sought. The Critically Endangered Yellow-crested Cockatoo occurs too infrequently on Lembata, as through much of its range, to obtain sufficient field data for population estimates using cumulative species lists. It may be possible to gather useful data on Flores Green Pigeon, as part of targeted surveys conducted during a longer period. Cumulative species lists are an ideal method for species-poor insular habitats. Ten species have been chosen here, though larger numbers of species $\left(15^{-20}\right)$ should be selected for larger islands. This method has potential for use by students, and others, during rapid status assessments of Indonesia's numerous islands. Distance methods should be considered where there are one or more key species of particular interest that are likely to occur at adequate densities.

\section{Habitat use}

This study found that two closed canopy forest types were relatively rich in forest birds, many of which were restricted-range species. In contrast, several increasingly disturbed lowland habitats were dominated by a suite of widespread generalist woodland species that characteristically have large global ranges. This is consistent with global and Wallacean patterns of increasing phylogenetic homogeneity with increasing disturbance (Lockwood et al. 2000). However, within-forest complex avifaunal patterns have been elucidated. Jones et al. (in press) found that endemic species and races of birds were able to exploit disturbed forest habitat on Sumba and Buru, although highly modified habitats were not sampled. Habitat associations of bird species on Lembata were in agreement with published information for Nusa Tenggara (Jones et al. 1995, Butchart et al. 1996, Coates and Bishop 1997). However several Wallacean endemics showed higher fidelity to closed canopy forest habitat, notably Wallacean Drongo, Yellow-spectacled White-eye and Black-fronted Flowerpecker. 
The clear bird-habitat patterns portrayed here are associated with intensity of human disturbance along an altitudinal gradient. With increasing altitude (and probably decreasing human population density) forest structure becomes more complex, trees are taller and canopy cover greater; deciduousness declines, the abundance of fruit increases, while nectar and seed resources tend to decline. Lowland swamp forest was an anomaly. Occurring at sea level it is among the best-developed forest on the island. However, at about 3 ha it is small, and as a consequence of either this or its low altitude it provided habitat for few regional endemics. The swamp forest avifauna is a mixture of nearby lowland habitats and mobile frugivores that are not constrained by particular altitudes or habitat.

Thirty-two new island records were reported (Trainor in review) with an expected island total of about 103 species. Biogeographical analyses have not been undertaken; however, this figure is low compared with the 119 species known for Roti (Coates and Bishop 1997), an island of comparable size and isolation from a neighbouring large island. Roti has several extensive freshwater wetlands, so that differences probably relate to the greater number of waterbird species.

\section{Conservation implications}

Land management is currently undergoing dynamic change in Lembata, as for much of Indonesia. In 2000, under a strategy of increasing regional autonomy the island became an independent kabupaten, or district, resulting in greater control over resource management issues, and greater local responsibility to find budget funds. The FAO/UNDP (1982) proposed the "Hadekewa-Labelakang forest" $\left(124.9 \mathrm{~km}^{2}\right)$ as a wildlife sanctuary. However, this area has not been managed for biological conservation and much of its forest cover has been lost through clearance for agriculture (author's unpubl. data). Management of the "Lamalera-Tanjung Suba" IBA (Rombang et al. in press) in the sparsely populated south-west Lembata offers an opportunity for protecting a representative selection of the island's habitats and species. The area (about $50 \mathrm{~km}^{2}$ ) harbours populations of Flores Green Pigeon with natural vegetation including Eucalyptus alba savanna, tropical dry forest and Lontar Palm savanna.

\section{Suggestions for additional study}

Lembata is of relatively low biodiversity significance and therefore a low priority for additional study in the context of Wallacea. However, a better understanding of the status and ecology of Flores Green Pigeon and Yellowcrested Cockatoo and the habitats they use would be valuable. Study of the latter species should concentrate on community interview to identify and describe any remaining populations and describe historical population trends and distribution. The abundance of Flores Green Pigeon may render it amenable to research on population size (and influence of hunting, if any), diet, and habitat use. Because of the lack of confusion species, community interview has potential to rapidly gather point-based records as well as descriptive biological information. Surveys are also needed to assess the status of Olive- 
headed Lorikeet (and other restricted-range birds) throughout its range. It remains common on Alor and Damar, but may have been extirpated from Kisar Island (author's unpubl. data) and is locally common on Adonara (Trainor 2002). It would also be useful to clarify the sub specific identity of several bird species on Lembata. Given that genetic variability generally follows the longitudinal axis in Nusa Tenggara (e.g. Schmitt et al. 2000), presumably these are referable to races found on Flores or Alor (see Appendix).

Closed canopy forest is well known to be vital habitat for forest birds, including most of Wallacea's restricted-range and globally threatened species (Stattersfield et al. 1998, BirdLife International 2001) but study along disturbance gradients, including various dryland agricultural systems would be valuable (in light of the rates of forest conversion to agriculture and other land uses).

\section{Acknowledgements}

I am grateful for BirdLife International-Indonesia Programme for facilitating permits through the Indonesian Forest Protection and Nature Conservation Department (PHKA), and providing field equipment. I wish to thank the village head of Puor who provided accommodation and guides during my brief stay. Review comments by Martin Jones significantly improved the manuscript, as did proof reading by Daryl Trainor. 
Appendix. Birds of Lembata: a preliminary list based on project records and those previously published.

\begin{tabular}{|c|c|c|c|c|c|c|c|c|c|c|}
\hline \multirow[t]{2}{*}{ Species } & \multirow[t]{2}{*}{ Status } & \multirow[t]{2}{*}{ Niche } & \multirow[t]{2}{*}{ Range } & \multirow[t]{2}{*}{ Freq. } & \multicolumn{6}{|c|}{ Habitat } \\
\hline & & & & & 1 & 2 & 3 & 4 & 5 & 6 \\
\hline Megapodius reinwardt & $\mathbf{R}$ & $\mathrm{F}, \mathrm{O}$ & & & & & & & & \\
\hline Coturnix ypsilophora raaltenii & $\mathbf{R}$ & G & Flo-Tan & 3 & 1 & 1 & & & 1 & \\
\hline Gallus gallus & $\mathbf{R}$ & $\mathrm{F}, \mathrm{O}$ & & 2 & & & & & & 1 \\
\hline Anas gibberifrons & $\mathbf{R}$ & $\mathrm{O}$ & & $\mathbf{I}$ & & & & 1 & & \\
\hline Turnix maculosa ?floresiana & $\mathbf{R}$ & G & ?Sbw-Lem & & & & & & & \\
\hline Turnix suscitator powelli & $\mathbf{R}$ & G & Lom-Alo & & & & & & & \\
\hline Dendrocopos moluccensis grandis & $\mathbf{R}$ & $\mathrm{F}, \mathrm{I}$ & Lom-Alo & 3 & & & & & & 1 \\
\hline Alcedo atthis floresiana & $\mathbf{R}$ & G & Lom-Rom & 2 & & & 1 & & & \\
\hline Halcyon capensis ?florensis & $\mathbf{R}$ & G & ?Lom-Lem & 2 & 1 & & 1 & & & \\
\hline Todiramphus chloris & $\mathbf{R}$ & G & & 17 & 1 & 1 & 1 & 1 & 1 & \\
\hline Merops philippinus & $\mathrm{Om}$ & $\mathrm{I}$ & & 1 & 1 & & & & & \\
\hline Merops ornatus & Am & I & & & & & & & & \\
\hline Eudynamys scolopacea & $\mathbf{R}$ & $\mathrm{F}, \mathrm{Fr}$ & & 13 & & 1 & & 1 & 1 & 1 \\
\hline Centropus bengalensis & $\mathbf{R}$ & $\mathrm{O}$ & & 14 & 1 & 1 & & 1 & 1 & 1 \\
\hline Trichoglossus euteles & R,rr & $\mathrm{F}, \mathrm{N}$ & & 8 & & 1 & 1 & & 1 & 1 \\
\hline Cacatua sulphurea & $\mathrm{R}, \mathrm{Cr}, \mathrm{Wa}$ & $\mathrm{F}, \mathrm{Fr}$ & & & & & & & & \\
\hline Collocalia esculenta ?sumbawae & $\mathbf{R}$ & I & ?Sbw-Lem & 5 & & & & & 1 & 1 \\
\hline Collocalia fuciphaga & $\mathbf{R}$ & $\mathrm{I}$ & & 2 & & & & & 1 & \\
\hline Hirundapus caudacutus & $\mathbf{V}$ & $\mathrm{I}$ & & $\mathbf{I}$ & & & & & 1 & \\
\hline Otus magicus albiventris & $\mathbf{R}$ & I & Lom-Lem & 2 & & & & & 1 & 1 \\
\hline Streptopelia chinensis & $\mathbf{R}$ & G & & 25 & & 1 & 1 & 1 & 1 & 1 \\
\hline Macropygia ruficeps orientalis & $\mathbf{R}$ & $\mathrm{F}, \mathrm{Fr}$ & Lom-Tim & 2 & & & & & & 1 \\
\hline Chalcophaps indica & $\mathbf{R}$ & $\mathrm{F}, \mathrm{Fr}$ & & 3 & & & & & 1 & 1 \\
\hline Geopelia maugei & $\mathbf{R}, \mathbf{W a}$ & G & NT \& Mal & 9 & 1 & & 1 & 1 & 1 & \\
\hline Treron floris & $\mathrm{R}, \mathrm{rr}$ & $\mathrm{F}, \mathrm{Fr}$ & Lom-Alo & 4 & & & & 1 & 1 & \\
\hline Ptilinopus cinctus ?everetti & $\mathbf{R}$ & $\mathrm{F}, \mathrm{Fr}$ & ?Lem-Alo & & & & & & & \\
\hline Ptilinopus melanospila & $\mathbf{R}$ & $\mathrm{F}, \mathrm{Fr}$ & & 9 & & & & 1 & 1 & 1 \\
\hline Ducula aenea & $\mathbf{R}$ & F,Fr & & 8 & & & $\mathrm{o}$ & & 1 & 1 \\
\hline Gallinago sp. (?megala) & Om & $\mathrm{I}$ & & & o & & & & & \\
\hline Numenius phaeopus & Pm & I & & 3 & 1 & & 1 & & & \\
\hline Tringa nebularia & Pm & I & & $\mathbf{I}$ & & & 1 & & & \\
\hline Tringa glareola & Pm & $\mathrm{I}$ & & $\mathbf{I}$ & 1 & & & & & \\
\hline Actitis hypoleucos & Pm & I & & 5 & 1 & & 1 & & 1 & \\
\hline Heteroscelus brevipes & Pm & I & & & 1 & & & & & \\
\hline Arenaria interpres & Pm & I & & 1 & 1 & & & & & \\
\hline Phalaropus lobatus & Pm & $\mathrm{I}$ & & & & & & & & \\
\hline Pluvialis fulva & Pm & I & & 4 & 1 & & & 1 & & \\
\hline Pluvialis squatarola & Pm & I & & 1 & 1 & & & & & \\
\hline Charadrius dubius & Pm & I & & $\mathbf{I}$ & 1 & & & & & \\
\hline Charadrius peronii & $\mathrm{R}, \mathrm{nt}$ & I & & $\mathbf{I}$ & 1 & & & & & \\
\hline Charadrius mongolus & Pm & I & & $\mathbf{I}$ & 1 & & & & & \\
\hline Sterna bergii & $\mathbf{R}$ & $\mathrm{P}$ & & $\mathbf{I}$ & 1 & & & & & \\
\hline Pandion haliaetus & $\mathbf{R}$ & $\mathrm{O}$ & & 4 & 1 & & 1 & & 1 & \\
\hline Haliastur indus & $\mathbf{R}$ & $\mathrm{O}$ & & 5 & 1 & & 1 & & 1 & \\
\hline Haliaeetus leucogaster & $\mathbf{R}$ & $\mathrm{O}$ & & 2 & 1 & & 1 & & & \\
\hline Circaetus gallicus & $\mathbf{R}$ & $\mathrm{O}$ & & 2 & & & & & 1 & \\
\hline Accipiter fasciatus wallacei & $\mathbf{R}$ & $\mathrm{O}$ & Lom-Dam & $\mathbf{I}$ & 1 & & & & & \\
\hline Accipiter gularis & Pm & $\mathrm{O}$ & & $\mathbf{I}$ & & & & & 1 & \\
\hline Falco moluccensis & $\mathbf{R}$ & $\mathrm{O}$ & & 8 & 1 & 1 & & 1 & 1 & $\mathrm{O}$ \\
\hline Phalacrocorax melanoleucos & $\mathbf{R}$ & $\mathrm{O}$ & & $\mathbf{I}$ & & & 1 & & & \\
\hline Egretta sacra & $\mathbf{R}$ & $\mathrm{O}$ & & 3 & 1 & & & & 1 & \\
\hline Ardea sumatrana & $\mathrm{R}, \mathrm{nt}$ & $\mathrm{O}$ & & $\mathbf{I}$ & & & 1 & & & \\
\hline
\end{tabular}


Appendix-Continued

\begin{tabular}{|c|c|c|c|c|c|c|c|c|c|c|}
\hline \multirow[t]{2}{*}{ Species } & \multirow[t]{2}{*}{ Status } & \multirow[t]{2}{*}{ Niche } & \multirow[t]{2}{*}{ Range } & \multirow[t]{2}{*}{ Freq. } & \multicolumn{6}{|c|}{ Habitats } \\
\hline & & & & & 1 & 2 & 3 & 4 & 5 & 6 \\
\hline Butorides striatus & $\mathbf{R}$ & $\mathrm{O}$ & & 3 & 1 & & 1 & & & \\
\hline Fregata ariel & $\mathbf{R}$ & $\mathrm{P}$ & & $\mathbf{I}$ & 1 & & & & & \\
\hline Pitta elegans concinna & $\mathbf{R}$ & $\mathrm{F}, \mathrm{O}$ & Lom-Alo & 2 & & & & & 1 & 1 \\
\hline Lichmera indistincta & $\mathbf{R}$ & $\mathrm{N}$ & & 3 & & 1 & 1 & & & \\
\hline Philemon buceroides neglectus & $\mathbf{R}$ & $\mathrm{F}, \mathrm{N}$ & Lom-Alo & 40 & 1 & 1 & 1 & 1 & 1 & 1 \\
\hline Gerygone sulphurea & $\mathbf{R}$ & $\mathrm{I}$ & & 6 & 1 & 1 & 1 & & 1 & \\
\hline Pachycephala pectoralis fulvotincta & $\mathbf{R}$ & $\mathrm{F}, \mathrm{I}$ & Sum-Alo & 15 & & & 1 & 1 & 1 & 1 \\
\hline Corvus macrorhynchos & $\mathbf{R}$ & $\mathrm{O}$ & & 7 & $\mathrm{O}$ & & 1 & & 1 & 1 \\
\hline Artamus leucorynchus & $\mathbf{R}$ & $\mathrm{I}$ & & 6 & & 1 & 1 & & 1 & 1 \\
\hline Oriolus chinensis broderipii & $\mathbf{R}$ & $\mathrm{F}, \mathrm{Fr}$ & Lom-Alo & 10 & & & & 1 & & 1 \\
\hline Coracina personata alfrediana & $\mathbf{R}$ & $\mathrm{F}, \mathrm{I}$ & Lem-Alo & & & & & & & \\
\hline Coracina novaehollandiae & Am & $\mathrm{I}$ & & & & & & & & \\
\hline Coracina tenuirostris ?timoriensis & $\mathbf{R}$ & $\mathrm{F}, \mathrm{I}$ & ?Lem-Tim & & & & & & & \\
\hline Lalage sueurii & $\mathbf{R}$ & I & & & & $\mathrm{O}$ & & & & \\
\hline Rhipidura diluta diluta & R,rr & $\mathrm{F}, \mathrm{I}$ & Flo-Lem & 6 & & & & & 1 & 1 \\
\hline Rhipidura rufifrons semicollaris & $\mathbf{R}$ & $\mathrm{F}, \mathrm{I}$ & Flo-Wet & 5 & & & 1 & 1 & & \\
\hline Dicrurus densus bimaensis & $\mathrm{R}, \mathrm{Wa}$ & $\mathrm{F}, \mathrm{I}$ & Lom-Alo & 26 & 1 & 1 & 1 & 1 & 1 & 1 \\
\hline Hypothymis azurea & $\mathbf{R}$ & $\mathrm{I}$ & & 13 & 1 & & o & 1 & 1 & 1 \\
\hline Tersiphone paradisi floris & $\mathbf{R}$ & $\mathrm{F}, \mathrm{I}$ & Sum-Alo & 1 & & & & & & 1 \\
\hline Monarcha trivirgatus trivirgatus & $\mathbf{R}$ & $\mathrm{F}, \mathrm{I}$ & Flor-Dam & & & & & & & \\
\hline Myiagra ruficollis & $\mathbf{R}$ & $\mathrm{F}, \mathrm{I}$ & & 3 & & & 1 & & & \\
\hline Culicicapa ceylonensis ?sejuncta & $\mathbf{R}$ & $\mathrm{F}, \mathrm{I}$ & ?Lom-Lem & 4 & & & & & & 1 \\
\hline Saxicola caprata & $\mathbf{R}$ & $\mathrm{I}$ & & 9 & 1 & 1 & & & 1 & \\
\hline Gracula religiosa venerata & $\mathbf{R}$ & $\mathrm{F}, \mathrm{Fr}$ & Lom-Alo & 2 & & & & & & 1 \\
\hline Parus major & $\mathbf{R}$ & I & & & & & & & & \\
\hline Hirundo rustica & $\mathrm{Pm}$ & $\mathrm{I}$ & & 3 & 1 & & & & 1 & \\
\hline Hirundo tahitica & $\mathbf{R}$ & $\mathrm{I}$ & & 4 & & & & & 1 & \\
\hline Hirundo striolata & $\mathbf{R}$ & I & & 1 & & & & & 1 & \\
\hline Cisticola juncidis & $\mathbf{R}$ & $\mathrm{I}$ & & 8 & 1 & 1 & & & & 1 \\
\hline Zosterops citrinellus & $\mathbf{R}$ & I & & & & & & & & \\
\hline Zosterops wallacei & R,rr & $\mathrm{I}$ & Sum-Lem & 14 & & & & & 1 & 1 \\
\hline Phylloscopus borealis & $\mathrm{Pm}$ & $\mathrm{F}, \mathrm{I}$ & & 5 & & 1 & & & 1 & 1 \\
\hline Mirafra javanica ?parva & $\mathbf{R}$ & $\mathrm{I}$ & Sum-Lem & $\mathbf{I}$ & 1 & & & & & \\
\hline Dicaeum agile tinctum & $\mathbf{R}$ & $\mathrm{Fr}$ & Sum-Alo & & & & & & & \\
\hline Dicaeum igniferum & $\mathrm{R}, \mathrm{rr}$ & $\mathrm{Fr}$ & & 16 & & & & & 1 & 1 \\
\hline Anthreptes malacensis convergens & $\mathbf{R}$ & $\mathrm{N}$ & Lom-Alo & & & & & & & \\
\hline Nectarinia jugularis & $\mathbf{R}$ & $\mathrm{N}$ & & 13 & 1 & & 1 & 1 & & o \\
\hline Nectarinia solaris solaris & R,rr & $\mathrm{N}$ & Sum-Alo & 18 & 1 & & 1 & & 1 & o \\
\hline Taeniopygia guttata guttata & $\mathbf{R}$ & G & Lom-Ser & 2 & 1 & & & & 1 & \\
\hline Lonchura punctulata blasii & $\mathbf{R}$ & G & Flo-Tan & 18 & 1 & 1 & & 1 & 1 & 1 \\
\hline Total species & & & & & 39 & 17 & 28 & 18 & 41 & 32 \\
\hline
\end{tabular}

Status: R, resident; Pm, Palearctic migrant; Om, Oriental migrant; Am, Austral migrant; V, Visitor; $\mathrm{Cr}$, Critically Endangered; Vu, Vulnerable; nt, Near Threatened; rr, Restricted-range.

Niche: F, Forest dependent; Fr, Frugivore; N, Nectarivore; I, Insectivore; G, Granivore; O, Omnivore; $P$, Piscivore.

Range, or Island distribution for Wallacean endemic species and Lesser Sundas endemic races: Alo, Alor; Dam, Damar; Flo, Flores; Lem, Lembata; Lom, Lombok; Mal, Maluku; NT, Nusa Tenggara; Rom, Romang; Sbw, Sumbawa; Ser, Sermata; Tan, Tanimbar Islands; Tim, Timor; Wet, Wetar;

Freq. is the number of "10-species lists" each bird species were recorded from.

Habitat. Presence or absence in six habitats is given; species recorded by "10-species list" are denoted by " 1 " and those observed only during general observations by " 0 ". Habitats were: 1 , Mangrove; 2, Coastal complex; 3, Swamp forest; 4, Eucalyptus alba savanna; 5, Tropical dry forest; 6, Tropical moist deciduous forest. 


\section{References}

Bappenas (1993) Biodiversity Action Plan for Indonesia. Jakarta: Ministry of National Development Planning/National Development Planning Agency.

Bibby, C., Jones, M. J. and Marsden, S. (1998) Expedition field techniques, bird survey. London: Royal Geographical Society.

Birdlife International (2001) Threatened birds of Asia: the BirdLife International Red Data Book. Cambridge, U.K.: BirdLife International. (http://www.rdb.or.id).

Butchart, S. H. M., Brooks, T. M., Davies, C. W. N., Dharmaputra, G., Dutson, G. C. L., Lowen, J. C. and Sahu, H. (1996) The conservation status of forest birds on Flores and Sumbawa, Indonesia. Bird Conserv. Internatn. 6: 335-370.

Coates, B. J. and Bishop, K. D. (1997) A guide to the birds of Wallacea. Alderley, Australia: Dove Publications.

Colwell, R. K. and Coddington, J. A. (1994) Estimating terrestrial biodiversity through extrapolation. Phil. Trans. R. Soc. Lond. B 345: 101-118.

FAO/UNDP (1982) National Conservation Plan for Indonesia, 4. Nusa Tenggara. Field Report 44 of FAO/UNDP National Parks Development Project INS/78/o61. Bogor, Indonesia: FAO.

FAO/UNDP (1983) National Parks Development Indonesia: project findings and recommendations. Terminal report. FO: DP/INS/78/o61. Rome: Food and Agriculture Organization of the United Nations and United Nations Development Programme.

Fjeldsa, J. (1999) The impact of human forest disturbance on the endemic avifauna of the Udzungwa Mountains, Tanzania. Bird Conserv. Internatn. 9: 47-63.

Gaston, K. J. and Blackburn, T. M. (1995) Birds, body size and the threat of extinction. Phil Trans. R. Soc. Lond. B 347: 205-212.

Hartert, E. (1898) On the birds of Lomblen, Pantar and Alor. Novit. Zool. 5: 455-476.

Inskipp, T., Lindsey, N. and Duckworth, W. A. (1996) Checklist of the Birds of the Oriental Region. Sandy, U.K.: Oriental Bird Club.

Johnstone, R. E., Jepson, P., Butchart, S. H. M., Lowen, J. C. and Prawiradilaga, D. (1996) The birds of Sumbawa, Moyo and Sangeang Islands, Nusa Tenggara, Indonesia. Rec. West. Aust. Mus. 18: 157-178.

Jones, M. J., Lindsley, M. D. and Marsden, S. J. (1995). Population sizes, status and habitat associations of the restricted-range bird species of Sumba, Indonesia. Bird Conserv. Internatn. 5: 21-52.

Jones, M. J., Sullivan, M. S, Marsden, S. J. and Lindsley, M. D. (2001). Correlates of extinction risk of birds from two Indonesian islands. Biol. J. Linn. Soc. 73: 65-79.

Jones, M. J., Marsden, S. J. and Linsley, M. D. (in press) Effects of habitat change and geographical variation on the bird communities of two Indonesian Islands. Biodiversity and Conservation.

Lambert, F. (1993) Trade, status and management of three parrots in the North Moluccas, Indonesia: White Cockatoo Cacatua alba, Chattering Lory Lorius garrulous and Violeteared Lory Eos squamata. Bird Conserv. Internatn. 3: 145-168.

Lockwood, J. L., Brooks, T. M. and McKinney, M. L. (2000) Taxonomic homogenisation of the global avifauna. Anim. Conserv. 3: 27-35.

Marsden, S. J. (1998) Changes in bird abundance following selective logging on Seram Conserv. Biol. 12: 605-611.

Mochtar, D. (1989) Laporan inventarisasi satwa liar kakatua jambul kuning (Cacatua sulphurea) dan beo (Gracula religiosa) di Kabupaten Flores Timur. Kupang: Perlindungan Hutan dan Pelestarian Alam.

Monk, K. A., de Fretes, Y. and Lilley, G. (1997) The ecology of Nusa Tenggara and Maluku. Singapore: Periplus Editions.

Noya, Y. and S. Koesoemadinata (1990) Geologi Lembar Lomblen, Nusatenggara Timur. Bandung: Indonesian Geological Research Development Centre. 
Poulsen, M. K. (1998). Biodiversity conservation priorities on Buru with special reference to the proposed Kepalat Mada Wildlife Sanctuary. Bogor: PHPA/BirdLife International-Indonesia Programme.

Poulsen, M. K. and Lambert, F. R. (2000) Altitudinal distribution and habitat preferences of forest birds on Halmahera and Buru, Indonesia: implications for conservation of Moluccan avifaunas. Ibis 142: 566-586.

RePPProT (1989) The land resources of Indonesia: a national overview. Jakarta: ODA/Ministry of Transmigration.

Rombang, W., Trainor, C. and Lesmana, D. (in press) Daerah penting bagi burung: Nusa Tenggara. Bogor, Indonesia: PHKA/BirdLife International-Indonesia Programme.

Schmitt, L. H., How, R. A, Hisheh, S, Goldberg, J. and Maryanto, I. (2000). Geographic patterns in two skink species along the Banda Arcs, southeastern Indonesia. J. Herpetol. 34: $240-258$.

SPSS (1999) SPSS brief guide. Chicago, IL: SPSS Inc.

Stattersfield, A. J., Crosby, M. J., Long, A. J. and Wege, D. C. (1998) Endemic Bird Areas of the world: priorities for biodiversity conservation. Cambridge, U.K.: BirdLife International (BirdLife Conserv. Series No. 7).

Trainor, C. and Lesmana, D. (2000) Exploding volcanoes, unique birds, gigantic rats and elegant ikat: identifying sites of international conservation significance on Flores, East Nusa Tenggara. Bogor, Indonesia: PKA/BirdLife International/WWF report 11.

Trainor, C. (2002) The birds of Adonara, Lesser Sundas, Indonesia. Forktail 18: 93-100.

Trainor, C. (in review). Birds of Lembata, Lesser Sundas, Indonesia. Kukila.

Verhoeye, J. and Holmes, D. A. (1999) The birds of the islands of Flores: a review. Kukila 10: $3-59$.

Wells, M. K., Guggenhiem, S., Khan, A., Wardojo, W. and Jepson, P. (1999). Investing in biodiversity: a review of Indonesia's integrated conservation and development projects. Washington D.C.: The World Bank.

White, C. M. N. and Bruce, M. D. (1986) The Birds of Wallacea (Sulawesi, the Moluccas and Lesser Sunda Islands Indonesia): an annotated check-list. London: British Ornithologists' Union (Check-list 7).

Whitten, T., Holmes, D. and MacKinnon, K. (2001) Conservation biology: a displacement activity for academia? Conserv. Biol. 15: 1-3.

COLIN R. TRAINOR

BirdLife International - Indonesia Programme, P.O. Box 310, Boo/Bogor, Indonesia

Permanent address: 3 Empire Court, Anula, 0812, Northern Territory, Australia. E-mail: Halmahera@hotmail.com

Received 23 January 2002; revision accepted 24 July 2002 